\title{
Review
}

\section{Implications of cytoplasmic male-sterility systems for development and deployment of pest resistant hybrids in cereals}

\author{
M.K. Dhillon ${ }^{1, *}$, H.C. Sharma ${ }^{1}$ and C.M. Smith ${ }^{2}$ \\ Address: ${ }^{1}$ International Crops Research Institute for the Semi-Arid Tropics (ICRISAT), Patancheru 502 324, Andhra Pradesh, India. \\ 2 Department of Entomology, Kansas State University, Manhattan, KS 66506-4004, USA.
}

*Correspondence: M.K. Dhillon. Email: m.dhillon@cgiar.org and mukeshdhillon@rediffmail.com

Received: $\quad 13$ September 2007

Accepted: $\quad 23$ July 2008

doi: 10.1079/PAVSNNR20083068

The electronic version of this article is the definitive one. It is located here: http://www.cababstractsplus.org/cabreviews

(C) CAB International 2008 (Online ISSN 1749-8848)

\begin{abstract}
The world population is increasing at an alarming rate, and there is a continued need to increase crop productivity to meet the food requirements. To meet the ever-increasing demand for food, cytoplasmic male-sterility (CMS) has been successfully exploited to develop hybrids for increasing crop production worldwide. However, large-scale cultivation of crop hybrids based on a single source of CMS may pose a serious challenge to sustainable crop production because of decreasing genetic diversity. This review analyses the potential for exploitation of different CMS systems for hybrid production, effects of CMS on various agronomic traits, and expression of resistance to insect pests and diseases in high-yielding hybrids of sorghum, maize, pearl millet, rice, wheat, and barley. Considerable information has been generated on the effects of CMS on physiology, yield, and agronomic characteristics of the plant. However, there is limited information on the effects of CMS on expression of resistance to insect pests and diseases. The available information indicates that the CMS lines are more susceptible to insect pests and diseases, and large-scale cultivation of hybrids based on a single source of CMS might result in pest outbreaks because of narrow genetic base. Therefore, there is a continuing need to evaluate various CMS systems in different genetic backgrounds for their effects on cultivar susceptibility to insect pests and diseases to develop strategies for large-scale deployment of pest-resistant hybrids on farmer's fields. Genetically engineered insect-resistant CMS lines can also be exploited to diversify the hybrid parents for sustainable crop production.
\end{abstract}

Keywords: Cytoplasmic male sterility, CMS systems, Cereals, Hybrids, Insect pests, Diseases, Resistance, Agronomic traits, Molecular characterization

Review Methodology: We searched the information from national and international journals and their cross references, newsletters, CAB Abstracts, AGRICOLA, and Web pages on the internet using the keywords such as cytoplasmic male-sterility, insect pests, diseases, sorghum, maize, rice, wheat, barley, pearl millet, cereals, hybrids, agronomic traits, molecular characterization, physiology, etc, individually or in different combinations, and analysed the information in relation to expression of resistance to insect pests, morphological and physiological traits, and development and deployment of hybrids based on CMS for sustainable crop production.

\section{Introduction}

Cytoplasmic male-sterility (CMS) results from the inability of plants to produce functional pollen because of reproductive deficiency in hermaphrodite flowers. In angiosperms, it may be the result of suppression of anthers (abortion, phyllody, petallody, or pistillody), aberrant meiosis (where anthers do not dehisce even if viable pollen is present), and the abortion of the androecium before pollen grains are formed (probably the result of premature dissolution of callose, and malformed androecium in which no pollen grains are formed) [1]. Malesterility based on gametophytes results from disturbances in normal microsporogenesis, which leads to formation of non-viable microspores because of mitochondrial mutations, barriers of the tapetal layer, and improper timing of 
callose activity and operon control [1]. Sporophyte-based male sterility may be conditioned by cytoplasmic, genetic, or cytoplasmic-genetic factors [1]. CMS occurs due to the mutation of mitochondria or some other cytoplasmic factors outside the nucleus, which results in the transformation of fertile cytoplasm into sterile cytoplasm. This CMS system is advantageous in ornamental species, as they tend to bloom and remain fresh longer than their fertile counterparts. The CMS is also useful for producing single/double-cross hybrids in crops where vegetative parts are the commercial product. However, it is unsuitable for hybrid seed production in crops where the fruit or seed is the commercial product. Genetic male sterility occurs in plants because of mutation at the fertility locus situated on a chromosome within the nucleus, and is usually governed by recessive genes. This type of male sterility is maintained by crossing male-sterile and male-fertile plants, and recovering the male-sterile segregants (1 sterile: 1 fertile). However, this system has not been used much in practical plant breeding because of maintenance problems. Cytoplasmic-genetic male sterility arises from the interaction of nuclear genes with the sterile cytoplasm, and is essentially a cytoplasmic sterility with a provision for restoration of fertility. Cytoplasmic genes exclusively control the male sterility. The term CMS, although a misnomer, has been widely used to describe genetic CMS.

\section{Influence of CMS on Physiology of Cereal Plants}

Increased accumulations of amino acids may also be related to their increased synthesis or non-utilization by male-sterile anthers. Once amino acid composition is altered, defective proteins are formed in male-sterile anthers, resulting in disruption of carbohydrate and protein metabolism [1-4]. Asparagine and glutamine are important vehicles of nitrogen transport in higher plants, and their accumulation influences pollen development and physiology. Reduced nucleic acid content has also been reported in male-sterile anthers of sorghum [5, 6] and barley [7]. Nucleic acid content increases in male-fertile wheat anthers, and decreases in T-type CMS anthers after the tetrad stage, and in Taign CMS system after the sporogenous cell stage [8].

The activity of several enzymes is also altered in malesterile lines. Cytochrome oxidase activity in male-sterile wheat anthers is greater than in male-fertile anthers [3], but deficient in abnormal anthers in sorghum [6], rice $[1,9]$, and maize [10], resulting in inefficient oxidative phosphorylation in anthers. Peroxidase activity is greater in sterile hybrids than in fertile hybrids and parents $[11,12]$. Male-sterile cytoplasm also has altered levels of ribulose-bisphosphate carboxylase (RUBPcase), adenosine triphosphatase (ATPase), and the plant defence enzymes during the later stages of growth, particularly under nitrate stress. Abnormal formation or dissolution of callose enzyme is also associated with male sterility in sorghum [13].

The CMS affects protein content and protein index $[14,15]$, but there is no effect of CMS on amylose content or starch viscosity [16]. The chlorophyll content is greater in CMS plants of barley, maize, rice, and wheat than in male-fertile plants [17]. The indole-3-acetic acid (IAA) content in anthers of male-sterile lines of maize is significantly lower than in the normal lines, but the zeatin content is higher in the CMS than in normal lines [18]. Murty et al. [19] observed substantial differences in soluble proteins, free amino acids, and peroxidase and esterase activity between CMS and maintainer lines in pearl millet. However, there were no differences in chlorophyll content and phenolics. Chhabra et al. [20] did not observe any differences in meiosis among isonuclear CMS lines, but chromosomal orientation and segregation were affected in the $A_{3}$ cytoplasm.

\section{CMS Systems in Different Cereal Crops}

\section{Sorghum}

CMS in sorghum was reported by Stephens and Holland [21] in crosses involving Dwarf Yellow Milo and Kafir, and Milo and Blackhull Kafir. The male-sterility resulted from introduction of Kafir genes into Milo cytoplasm. This malesterility system is based on cytoplasmic-genetic male sterility instead of CMS, since the male sterility is based on the interaction between Milo cytoplasm and Kafir nuclear genes [21, 22]. The degree of male sterility increases with an increase in the proportion of Kafir genes in Milo cytoplasm. The recessive genes $\mathrm{msc}_{1}$ and $\mathrm{msc}_{2}$, present in Milo cytoplasm result in male sterility. In addition to Milo $\left(A_{1}\right)$ cytoplasm, cytoplasmically male-sterile lines are also available in the $A_{2}, A_{3}, A_{4}, A_{4} M, A_{4} V z M, A_{4} G_{1}, A_{5}, A_{6}, 9 E$, and Kansas (KS) cytoplasms [23-28], but their heterotic potential has not been exploited because of a lack of appropriate restorers. Changes in mitochondrial genome and in DNA clones derived from the genes of known function are responsible for male sterility [29-31], and internal mitochondrial transcription processing has been reported to be correlated with fertility restoration [32-36]. The restriction fragment length polymorphisms (RFLPs) using mitochondrial DNA (mtDNA) clones as probes and chloroplast DNA (ctDNA) restriction endonuclease fragments have been reported to be useful as molecular tools for fingerprinting sterility-inducing cytoplasms, determining CMS among germplasm accessions, and identifying new sources of cytoplasm with a potential to induce male sterility to broaden the base of CMS systems [37-46] (Table 1). Restriction endonuclease patterns of ctDNA have also been reported to distinguish fertile and male-sterile cytoplasms [47]. The $A_{1}$ (milo) cytoplasm has been widely deployed for producing sorghum hybrids. The $A_{2}$ cytoplasm has been deployed for 
Table 1 Molecular differentiation of male-sterile and fertile cytoplasms in sorghum

\begin{tabular}{|c|c|c|}
\hline Technique/gene/marker/clone & Characteristics & References \\
\hline $\mathrm{N}_{1}$ and $\mathrm{N}_{2}$ plasmid-like DNAs & $\begin{array}{l}\text { Differentiated } A_{3} \text { cytoplasm of IS } 12563 \mathrm{C} \text { and IS } 1112 \mathrm{C} \text { at } \\
\text { plasmid sizes } 1.7 \text { and } 2.3 \mathrm{~kb} \text {. }\end{array}$ & [37] \\
\hline Restriction endonuclease enzymes & $\begin{array}{l}\text { Differentiated sterile and fertile, and } A_{1}, A_{2}, A_{3} \text { and } A_{4} \\
\text { CMS cytoplasms. }\end{array}$ & [38] \\
\hline coxl clone & $\begin{array}{l}\text { Differentiated } 9 \mathrm{E} \text { (IS 17218) and } \mathrm{A}_{4} \text { (IS } 7920 \mathrm{C} \text { ) cytoplasms } \\
\text { at Hin dIII fragment size } 1.9 \mathrm{~kb} \text {. }\end{array}$ & [39] \\
\hline atp6 probe & Differentiated $9 \mathrm{E}$ and $\mathrm{A}_{4}$ cytoplasms. & {$[40]$} \\
\hline$r r n 18$ and $r r n 26$ probes & Differentiated between KS 37 and KS 39 . & [40] \\
\hline orf107 gene & Mitochondrial gene orf107 is associated with male-sterility. & [40] \\
\hline atp 6 probe & Differentiated Texas fertile and $A_{3}$ cytoplasms at orf25. & {$[25,41]$} \\
\hline Restriction enzyme & $\begin{array}{l}\text { The } A_{1} \text { and } A_{2} \text { cytoplasms have identical HindIII patterns, } \\
\text { while Bam HI-digested ctDNA produced the same patterns } \\
\text { in } A_{2}, A_{3} \text { and } A_{4} \text {, and Eco RI and Pst I produced identical } \\
\text { patterns in all four cytoplasms. }\end{array}$ & {$[42]$} \\
\hline RFLPs & $\begin{array}{l}\text { Classified Indian origin CMS (Maldandi, Guntur, Vizianagaram) } \\
\text { as Indian } \mathrm{A}_{4} \text { types, and distinguished from the American } \\
\mathrm{A}_{4-} \text { and } \mathrm{A}_{1} \text {-types. }\end{array}$ & [43] \\
\hline RFLPs & $\begin{array}{l}\text { Mitochondria of fertile } 2219 \mathrm{~A} \text { have more respiring efficiency and } \\
\text { mitochondrial electron transport (ET) rates from NADH to oxygen } \\
\text { than CMS line, thus indicating responsible for male sterility. }\end{array}$ & {$[44,45]$} \\
\hline RFLPS & $\begin{array}{l}\text { Restriction fragment locations of various mitochondrial genes and } \\
\text { their transcripts suggest polymorphism for genes related to the } \\
\text { ATP synthase complex between CMS and maintainer cytoplasms. }\end{array}$ & [46] \\
\hline
\end{tabular}

hybrid production in China [48]. Different CMS systems and the maintainer and restorer lines have also been analysed for their influence on expression of resistance to biotic and abiotic stresses and agronomic traits.

\section{Rice}

Sampath and Mohanty [49] first emphasized the role of cytoplasm in inducing male sterility in rice, and later, Japanese scientists reported several sources of CMS. The first cytoplasmically male-sterile line was developed by substituting nuclear genes of the indica variety, Taichung Native 1 [50]. This CMS line had poor plant type, unstable sterility, and was photoperiod-sensitive, and thus could not be used in hybrid seed production. There are three major types of CMS (HL, BT and WA), and two types of GMS systems (photoperiod-sensitive and temperature-sensitive) in rice. The BT- and HL-type CMS genes have been characterized as orf-79 and orfH79 [51]. However, with the advent of wild abortive (WA) cytoplasm from wild rice (Oryza sativa f. spontanea or Oryza rufipogon or Oryza perenis) in China, about $95 \%$ of the CMS lines currently used in producing rice hybrids have been derived from this source [52]. A large number of CMS lines in rice have also been developed by exploiting intra- and inter-specific cytoplasmic differences [53-56]. The genes encoding and restoring CMS have been mapped using different techniques [57-63]. The restorer allele $R f-1$ is present in some indica rice lines, whereas most lines of the subspecies japonica carry a non-restoring $R f-1$ allele [62]. The fertility in the WA CMS system is controlled by more than two loci [63]. The fertility restorer genes $R f-3$ and $R f-5$, have been mapped on to the short arms of chromosomes 1 and 10, respectively, while Rf-4 and Rf-6 genes have been mapped on the long arm of chromosome 10 [51, 64, 65]. The Rf-1 gene encodes a PPR protein associated with functions in fertility restoration of CMSBoro II and BT-type male-sterile cytoplasms [66-69].

\section{Wheat}

Male sterility in wheat was first reported by Kihara [70], with the discovery of male-sterile cytoplasm from Aegilops candida. Majority of these systems are not usable because of reduced vigour, abnormal plant morphology, zygote elimination, reduced seed set, fertility variation, and delayed maturity. Fertility restoration genes in wheat have not been discovered, and to date, only Triticum timopheevii has shown potential for development of a wheat fertility restoration system [71]. Triticum aestivum cv. Norin 26, which contains Aegilops crassa alloplasm, is nearly male-sterile under long-day length $(>15 \mathrm{~h})$, but is highly male-fertile under short-day length $(<14.5 \mathrm{~h})$. Ethylmethane-sulphonate-induced mutagenesis has also been used to obtain photosensitive CMS lines [72]. Wheat cultivars with a restorer gene, Rfv1 located on the short arm of chromosome IB, which contains the IBL-IRS, can be used to develop wheat hybrids with SV CMS [73]. Fertility restoration for $T$. timopheevii CMS in wheat is controlled by major fertility restorer $(R f)$ and modifier genes [74]. There is considerable genotype $\times$ environment 
Table 2 Molecular differentiation of male-sterile and fertile cytoplasms in maize

\begin{tabular}{|c|c|c|}
\hline Technique/gene/marker/clone & Characteristics & References \\
\hline urf13TW gene & $\begin{array}{l}\text { The urf13TW gene, derived from the mitochondrial gene } \\
\text { T-urf13 responsible for Texas CMS has been expressed in } \\
\text { Saccharomyces cerevisiae by targeting the urf13TW } \\
\text { translation product into mitochondria. }\end{array}$ & [79] \\
\hline$T$-urf13 gene & $\begin{array}{l}\text { The mitochondrial } 35 \text { bp open reading frame } T \text {-urf } 13 \text { shares } \\
\text { a } 165 \mathrm{~kb} \text { sequence duplication with CMS T. }\end{array}$ & {$[80]$} \\
\hline orf355 and orf77 genes & $\begin{array}{l}\text { The mitochondrial open reading frames orf355 and orf77 } \\
\text { are associated with CMS-S, and orf } 77 \text { and the mitochondrial } \\
\text { ATP synthase subunit atp9 share common sequence. }\end{array}$ & [81] \\
\hline$R$ gene & $\begin{array}{l}\text { The nuclear gene Rf3 suppresses the CMS-S phenotype, } \\
\text { decreases the abundance of the major } R \text { gene transcripts, } \\
\text { including the CMS-S-specific } 1.6 \mathrm{~kb} \text { mRNA, in mitochondria } \\
\text { of restored plants. }\end{array}$ & {$[82]$} \\
\hline T-urf13 gene & $\begin{array}{l}\text { T-urf13 confers Texas CMS in maize plants. S. cerevisiae } \\
\text { nucleii transformed with the universal code equivalent of } \\
T \text {-urf13 mimic } T \text {-urf13 effects in maize and limit respiration. }\end{array}$ & [83-84] \\
\hline $\begin{array}{l}\text { mtDNA restriction endonuclease } \\
\text { fragment analysis }\end{array}$ & $\begin{array}{l}\text { There is heterozygosity in mtDNA among normal fertile and } \\
\text { male-sterile cytoplasms, due to changes in ctDNA, which may } \\
\text { affect CMS in maize. }\end{array}$ & [85-87] \\
\hline$R f 4$ and $R f 5$ restorer genes & $\begin{array}{l}\text { Fengke } 1 \text { line contains } R f 4 \text { and } R f 5 \text { duplicating restorer genes } \\
\text { located on } 5 \mathrm{~L} \text { and } 8 S \text { chromosomes, respectively. }\end{array}$ & [88-91] \\
\hline
\end{tabular}

$(\mathrm{G} \times \mathrm{E})$ effect, which makes it difficult to develop CMSbased hybrids.

\section{Maize}

CMS in maize was reported by Rhodes [75], and restorer/ maintainer reaction patterns have since been differentiated into three types: CMS-T (Texas), CMS-S (USDA) and CMS-C (Charrua) by Duvick [76] and Beckett [77]. Prior to 1970, CMS-T was used extensively, as it imparted full sterility in most of the inbred lines, and fertility restoration was relatively easy. However, CMS-T was not used for hybrid seed production because of susceptibility to southern corn leaf blight [Bipolaris maydis (Nisik. \& Miyake)], which severely damaged the maize crop in the USA [78]. The epidemic resulted from a new race (T-race) of $B$. maydis, which was extremely virulent to cultivars containing the T-cytoplasm. Subsequently, molecular techniques have been deployed for differentiating male-sterile and male-fertile cytoplasms, and a number of genes responsible for CMS and restoration have been identified and used for making hybrids in maize [79-91] (Table 2). Mitochondrial gene T-urf13 confers Texas-type CMS in maize plants [84], but some restorer genes interfere with the expression of corresponding sterility genes at development- or tissue- or organ-specific stages. The control of expression of a mitochondrial sterility gene by a nuclear restorer gene represents a valuable model for the study of interactions between nuclear and mitochondrial genomes in higher plants. However, restriction endonuclease fragment analysis of organelle DNA demonstrated the heterozygosity in mtDNA among normal fertile [85] and male-sterile [86] cytoplasms, suggesting that changes in ctDNA [87] may affect CMS in maize.

\section{Pearl Millet}

Since the discovery of cytoplasmic-genetic male-sterility in Tift 23A ( $A_{1}$ cytoplasm), several CMS sources have been identified [92, 93]. Tift 23A has excellent agronomic characteristics and combining ability, and has been widely used for hybrid production in India and the USA. The $A_{2}$ and $A_{3}$ cytoplasms have been identified, but have not been used in commercial hybrid production because of unstable sterility [92]. An $A_{4}$ cytoplasm from a wild subspecies of pearl millet, Pennisetum americanum subsp. monodii has been found to be stable for male-sterility, and is different from $A_{1}, A_{2}$ and $A_{3}$ cytoplasms [93]. Although, a very high frequency of $A_{4}$ restorer genes occurs in wild relatives of pearl millet, restorer genes for this cytoplasm occur in a low frequency in cultivated germplasm. Many unique sources of male-sterility have also been identified by using mtDNA RFLP, but there is a need to find restorers for these CMS systems [94-95].

\section{Barley}

CMS in barley was discovered from a population of alloplasmic Hordeum jubatum cytoplasm [96]. Hordeum vulgare acts as a perfect maintainer for this system, but fertility restorers have not been identified [97]. The two CMS, $m s m_{1}$ and $m s m_{2}$ have restorer genes [98-101], and Rfm1a gene restores the fertility of $\mathrm{msm}_{1} \mathrm{CMS}$ lines, but none of these are complete restorers. Locus msg50, with alleles 
msg50gh and $\mathrm{msg} 50 \mathrm{hm}$, is responsible for the male-sterile genes msggh and msghm [102]. Several molecular markers linked to Rfm1 locus have been identified on chromosome $6 H$ [103].

\section{Effects of CMS on Agronomic Traits}

An understanding of cytoplasmic influences on yield and agronomic characters could have a major bearing on improving crop productivity, since cytoplasm is contributed by the seed parent to its progeny. Cereals are the major component of human diets, and the exploitation of CMS for increasing crop production, productivity, and value addition is crucial to meet the increased demand for food in future. Studies conducted on effects of CMS on various agronomic and yield traits such as plant height, unit seed weight, grain yield, leaf and panicle traits, days to $50 \%$ flowering, etc., in major cereals (sorghum, maize, pearl millet, rice, wheat and barley) in the past are given in Table 3 [104-168].

\section{Effects of CMS on Expression of Resistance to Plant Diseases}

Tan-coloured CMS lines in combination with tan restorer lines produce hybrids with high levels of resistance to rust (Puccinia purpurea Cooke) and head blight (Fusarium spp.) in sorghum. Hybrids based on red CMS lines $\times$ tan restorer lines are also resistant to these diseases, while red $\times$ red and $\tan \times$ red hybrids are susceptible $[169,170]$, suggesting that characteristics of the restorer parent are dominant over the CMS line. Cytoplasm had no effect on head blight incidence or grain mould (Fusarium moniliforme J. Sheld) severity [171]. The hybrids based on $A_{2} C M S$ system have 14-19\% more smut (Sporisorium reilianum (Kuhn) Landon and Fullerton) and 6\% more grain mould incidence than the hybrids based on $A_{1}$ cytoplasm [171173].

Wheat hybrids based on Aegilops juvenalis cytoplasm have greater resistance to powdery mildew (Erysiphe graminis É.J. Marchal) and better seed germination than the hybrids based on A. kotschyi cytoplasm [132]. Cytoplasm accounts for $23.5 \%$ of the variance in Puccinia recondita Roberge resistance at the seedling stage in alloplasmic lines with bread wheat nucleus (Penjamo 62), and $17.4 \%$ at the adult stage [174]. Newly developed mt-A lines (IBL-IRS chromosome-inhibited lines) have been reported to be resistant to both $E$. graminis and $P$. recondita, but SV-A lines (SV cytoplasm-substituted lines) are susceptible to these pathogens. Mantle and Swan [175] observed $>20 \%$ sclerotia of ergot (Claviceps purpurea (Fr.) Tul.) in threshed grain of poorly pollinated male-sterile wheat plants as compared with $0.7 \%$ sclerotia in the fertile plants.
The male-sterile barley cytoplasms ( $\mathrm{msm}_{1}$ and $\left.\mathrm{msm}_{2}\right)$ have no effect on expression of resistance to barley yellow mosaic virus (BaYMV) transmitted by Polymyxa graminis Ledingham, but the Fusarium head blight (Fusarium graminearum Schwabe) damage is greater in fertile than in the sterile lines, indicating that pollen or anthers are important for infection by $F$. graminearum [176]. Malesterile lines based on $\mathrm{msm}_{1}$ cytoplasm without pollen have lower Fusarium head blight infestation than in the maintainer lines [176].

Male-sterile cytoplasm affects the rice plant's reaction to pathogens, as the WA male-sterile cytoplasm is less susceptible to rice blast (Pyricularia oryzae Cavara) and bacterial blight [Xanthomonas campestris pv. oryzae (Xoo)] than the fertile cytoplasm [177]. The $P$. oryzae resistant rice hybrids have been obtained from highly resistant A-lines $\times$ moderately resistant $\mathrm{R}$-lines, while moderately resistant $A$-lines $\times$ highly susceptible $R$-lines produced moderately resistant hybrids. Susceptible A-linesusceptible R-line crosses produced susceptible hybrids [178]. Thus, resistance is required in both $A$ - and $R$-lines to produce pathogen-resistant hybrids. To incorporate bacterial leaf blight (Xanthomonas oryzae pv. oryzae) resistance in rice hybrids, it is desirable to have resistance in both CMS and restorer lines, because the disease is not only affected by nuclear genes, but also by the sterile cytoplasm [179, 180]. Conversely, Fusarium sheath rot (F. moniliforme) and Karnal smut (Tilletia barclayana Sacc. \& P. Syd.) diseases have been found to be more severe on CMS lines and hybrids as compared to that on the maintainer and restorer lines [181].

Susceptibility in Texas CMS maize lines to southern corn leaf blight [B. maydis] and yellow leaf blight (Phyllosticta maydis Arny \& Nelson) are associated with the unusual mitochondrial gene T-urf 13, which encodes a $13 \mathrm{kDa}$ polypeptide (urf13) in comparison with normal C- or S-cytoplasm $[182,183]$. Interactions between fungal toxins and urf13 polypeptide result in inner mitochondrial membrane permeability, and account for susceptibility to these fungal pathogens. Plants with the Texas CMS are also more susceptible to the toxins from the pathogens than that of the normal fertile plants, and those with other types of CMS [184]. There are no unfavourable effects of $\mathrm{C}$ - and M-type CMS in maize on expression of resistance to Ustilago zeae (Schwein.) Unger and Sphacelotheca reiliana (Kühn) Clinton under natural infection, but C-type cytoplasm is susceptible to smut, and M-type to $U$. zeae and stalk rot, Physoderma maydis (Miyabe) Miyabe [150]. In addition, C-type CMS was resistant to Cochliobolus heterostrophus (Drechs.) Drechs. and Setosphaeria turcica (Luttrell) Leonard et Suggs [185]. The sub group Cl (CMSC) of group $C$ is susceptible to $B$. maydis race $C$, but the subgroups CII (CMS-RB) and CIII (CMS-ES) are not infected seriously [186].

In pearl millet, incidence of downy mildew [Sclerospora graminicola (Sacc.) Schroet.] was similar in hybrids carrying either $A_{1}$ male-sterile or B-cytoplasm [187], and there 
Table 3 Influence of male-sterile/male fertile cytoplasms on agronomic traits in different cereal crops

\begin{tabular}{|c|c|c|c|}
\hline Crop/traits & Cytoplasm & Effect & References \\
\hline $\begin{array}{l}\text { Sorghum } \\
\text { Grain yield, seeds/panicle, } 100 \text {-seed weight, panicles per plant, } \\
\text { leaf length and area, leaves per plant, and days to flowering. }\end{array}$ & $\mathrm{MS}^{1}$ versus $\mathrm{MF}^{2}$ & Yes & {$[104]$} \\
\hline Grain yield components & MS versus MS & No & [104] \\
\hline $\begin{array}{l}\text { Grain yield, plant height, panicle length and excretion, } \\
\text { flowering, and grain moisture }\end{array}$ & MS versus MS & No & {$[104-108]$} \\
\hline Plant height and days to $50 \%$ flowering & $\begin{array}{l}\text { MS versus MS and } \\
\text { MS versus MF }\end{array}$ & Yes & [109-110] \\
\hline Grain yield and other agronomic traits & MS versus MS & No & {$[111-112]$} \\
\hline Grain size, yield and yield components & MS versus MS & Yes & {$[113-114]$} \\
\hline GCA and SCA of morphological traits & MS versus MS & Yes & [114] \\
\hline Days to flowering, inflorescence length and plant height & MS versus MS & No & {$[115]$} \\
\hline Agronomic and morphological traits, pollen fertility and seed set & MS versus MS & Yes & [116-118] \\
\hline Heterosis for yield & MS versus MF & Yes & [119] \\
\hline Days to flowering, plant height, grain yield and forage quality & MS versus MF & No & {$[120]$} \\
\hline Seed setting & MS versus MS & Yes & [120] \\
\hline \multicolumn{4}{|l|}{ Wheat } \\
\hline Grain weight and texture & MS versus MF & Yes & [121] \\
\hline Agronomic traits & MS versus MF & No & [122-123] \\
\hline & MS versus MS & Yes & [122-123] \\
\hline $\begin{array}{l}\text { Number of tillers, ear length, seed setting, days to maturity, } \\
\text { yield/panicle, and grain yield }\end{array}$ & MS versus MF & Yes & {$[124-126]$} \\
\hline 1000-grain weight, ear density, flag leaf length, and winter hardiness & MS versus MF & No & [126] \\
\hline Agronomic traits, except ear length & MS versus MS & No & {$[124]$} \\
\hline $\begin{array}{l}\text { Panicle emergence, spikelet number, kernel texture, } \\
\text { germination rate, and grain weight/plant }\end{array}$ & MS versus MF & Yes & {$[127]$} \\
\hline Grain quality & MS versus MF & No & {$[127]$} \\
\hline Internodes length and plant height & MS versus MF & Yes & [128] \\
\hline Bread making, and agronomic or yield traits & MS versus MS & No & [129] \\
\hline Grain yield, panicle emergence, days to flowering, and height & MS versus MF & Yes & [130] \\
\hline Grain yield & MS versus MF & Yes & [131] \\
\hline Agronomic characters & MS versus MS & No & [132] \\
\hline Seed germination & & Yes & [132] \\
\hline \multicolumn{4}{|l|}{ Barley } \\
\hline $\begin{array}{l}\text { 1000-grain weight, effective panicles/plant, grains/panicle, plant } \\
\text { height, length of peduncle and total grain weight/plant }\end{array}$ & MS versus MF & Yes & [133] \\
\hline Morphological and yield characteristics & MS versus MF & No & {$[134]$} \\
\hline \multicolumn{4}{|l|}{ Rice } \\
\hline Grain yield & MS versus MF & Yes & {$[135-142]$} \\
\hline Panicle number, panicle length and grain yield & $\begin{array}{l}\text { MS versus MS and } \\
\text { MS versus MF }\end{array}$ & Yes & {$[143]$} \\
\hline Pollen and spikelet sterility & MS versus MS & Yes & [144] \\
\hline Dry matter in early growth stages and yield & MS versus MF & Yes & {$[145-146]$} \\
\hline \multicolumn{4}{|l|}{ Maize } \\
\hline Stability and phenotypic expression of growth & MS versus MF & No & [147] \\
\hline Stem breakage/lodging and grain yield & MS versus MF & Yes & [148-149] \\
\hline Hybrid heterosis & MS versus MF & Yes & {$[150-151]$} \\
\hline Grain moisture content and stem breakage at harvest & MS versus MS & No & [152-153] \\
\hline Grain yield & MS versus MF & Yes & [154] \\
\hline Plant height, tassel length, branches/tassel, and yield & MS versus MS & Yes & {$[155]$} \\
\hline $\begin{array}{l}\text { Grain yield, ears per plant, grains per ear, } \\
\text { tassel length, and tassel branches }\end{array}$ & MS versus MF & No & [156] \\
\hline Yield and morphological traits & MS versus MF & No & {$[157-158]$} \\
\hline \multicolumn{4}{|l|}{ Pearl millet } \\
\hline Grain yield, and leaf and peduncle lengths & MS versus MS & Yes & [159] \\
\hline $\begin{array}{l}\text { Grain yield, and leaf and peduncle lengths, } \\
\text { and commercial hybrid production }\end{array}$ & MS versus MS & No & {$[160-161]$} \\
\hline Grain yield & MS versus MS & Yes & {$[162-165]$} \\
\hline Dry matter production & $\begin{array}{l}\text { MS versus MS and } \\
\text { MS versus MF }\end{array}$ & No & {$[162-165]$} \\
\hline Plant height, days to flowering, dry matter yield, and grain yield & MS versus MF & Yes & [166] \\
\hline Stability of male-sterility & MS versus MS & Yes & [167] \\
\hline $\begin{array}{l}\text { Earliness, panicle weight, length and girth, } \\
\text { number of tillers, and grain yield }\end{array}$ & MS versus MS & Yes & [168] \\
\hline
\end{tabular}

${ }^{1} \mathrm{MS}=$ male-sterile cytoplasm

${ }^{2} \mathrm{MF}=$ male-fertile cytoplasm. 


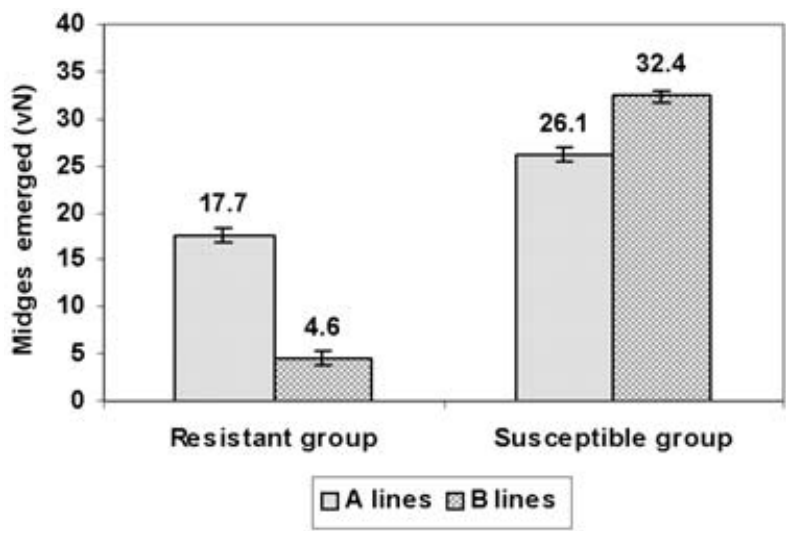

Figure 1 Effect of CMS on midge, Stenodiplosis sorghicola adult emergence in resistant and susceptible groups of CMS (A) and maintainer (B) lines of sorghum [198]

was no effect of different CMS systems on expression of resistance to downy mildew [188]. The $A_{1}$ cytoplasm confers moderate susceptibility to smut (Tolyposporium penicillariae Brefeld), downy mildew, and leaf blight (Xanthomonas spp.) in $\mathrm{A}_{1}$-based pearl millet hybrids [189]. In the case of $T$. penicillariae, pollination affects disease development [190], and susceptibility to smut may be attributed to cytoplasmic $\times$ nuclear interaction effects [191]. High ergot (Claviceps fusiformis Loveless) susceptibility in pearl millet hybrids has been associated with the $A_{1}$ cytoplasm, but highly resistant hybrids have been obtained from the crosses of highly resistant $A$ - and R-lines [192]. The A-lines are more susceptible to smut than the B- and R-lines. Thakur et al. [193] noted that open-pollinated varieties are less susceptible to ergot than the $F_{1}$ hybrids. Pearl millet hybrids based on $A_{1}$ cytoplasm are also more susceptible to smut than the openpollinated varieties [194]. The A-line-based hybrids had higher smut severity than the hybrids based on B-lines, indicating that CMS rather than the $A_{1}$ cytoplasm per se resulted in greater smut severity in A-line hybrids. However, the hybrids based on smut-resistant $A$ - and R-lines were as resistant as the hybrids based on $B$-lines. The $A_{2}$, $A_{3}$, and $A_{4}$ cytoplasms are not linked to downy mildew susceptibility, and can be exploited commercially for hybrid production [195]. Hybrids based on $A_{2}, A_{3}$ and Violaceum CMS systems have better downy mildew, ergot and smut resistance, and can be exploited commercially for hybrid production [161].

\section{Effects of CMS on Expression of Resistance to Insect Pests}

Most of the sorghum hybrids grown in India are based on the $A_{1}$ cytoplasm, which is highly susceptible to insect pests $[196,197]$. Ross and Kofoid [105] reported that the Kansas lines KS 34 to KS 39 based on Kansas CMS system are as susceptible as CKA (Combine Kafir-based CMS

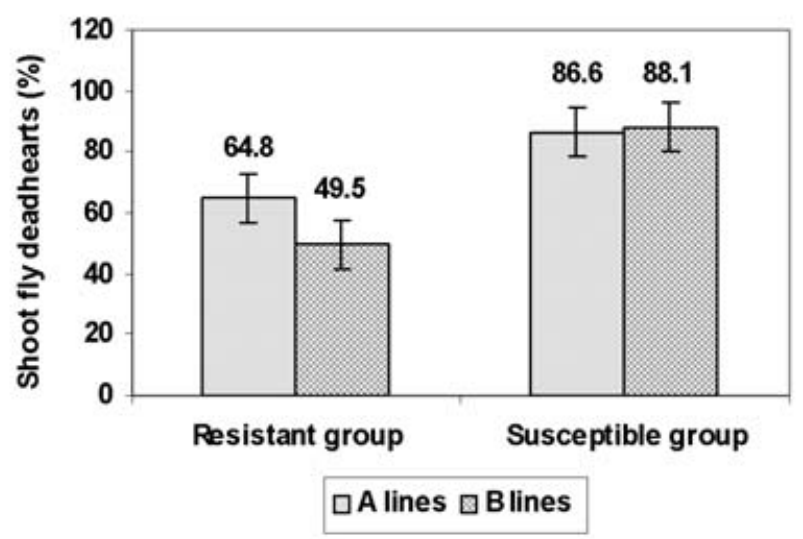

Figure 2 Effect of CMS on expression of resistance to shoot fly, Atherigona soccata in resistant and susceptible groups of CMS (A) and maintainer (B) lines of sorghum [203]

lines) to the greenbug, Schizaphis graminum (Rondani). Sharma et al. [198] recorded low damage by the sorghum midge, Contarinia sorghicola (Coqillett), and reduced midge emergence on midge-resistant B-lines as compared with corresponding A-lines (Figure 1). However, there were no differences in midge damage or adult emergence between midge-resistant and -susceptible A-lines. Midgeresistant $\mathrm{CMS} \times$ susceptible restorer-based hybrids are less susceptible to $C$. sorghicola damage than susceptible CMS $\times$ susceptible restorer-based hybrids [199-201].

The expression of non-preference and antibiosis components of resistance to southwestern corn borer, Diatraea grandiosella Dyar and sugarcane borer, Diatraea saccharalis Fab. was better in resistant inbred lines based hybrids CML $67 \times$ CML 135 and CML $139 \times$ CML 135 than the inbreds [202]. These hybrids also suffered low leaf and stalk damage, and grain yield loss $(3-4 \%)$ in comparison with the susceptible hybrid Ki $3 \times$ CML 131 (35-40\%). The oviposition and deadheart formation on main plants and tillers by the sorghum shoot fly, Atherigona soccata (Rondani), are significantly lower on maintainer lines compared with the CMS lines [203] (Figure 2). Larval development was prolonged and pupal mortality was greater on maintainer lines than on the CMS lines, wheras pupal weights and fecundity were greater on the CMS lines [203]. The maintainer lines showed better recovery resistance than the CMS lines, but such differences were more apparent in the shoot fly-resistant CMS and maintainer lines as compared to shoot fly-susceptible CMS and maintainer lines. Expression of morphological traits such as leaf glossiness, trichomes, and leaf surface wetness (which are associated with resistance to shoot fly) was better in the maintainer lines as compared to the CMS lines [204]. The shoot bug (Peregrinus maidis Ashmead)- and sugarcane aphid [Melanaphis sacchari (Zehntner)]-resistant CMS lines suffered more damage than the B-lines, whereas such 


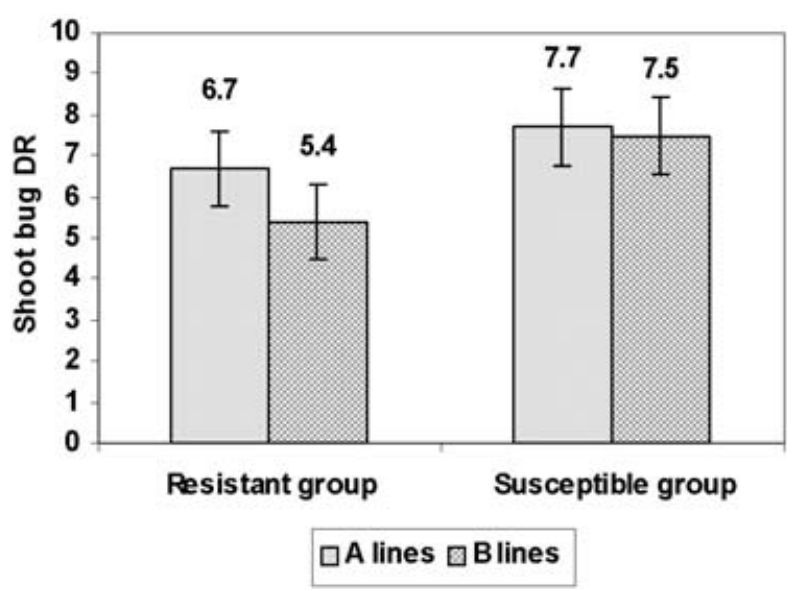

Figure 3 Effect of CMS on shoot bug, Peregrinus maidis damage in resistant and susceptible groups of CMS $(A)$ and maintainer $(B)$ lines of sorghum. $D R=$ damage rating (1-9) [205]

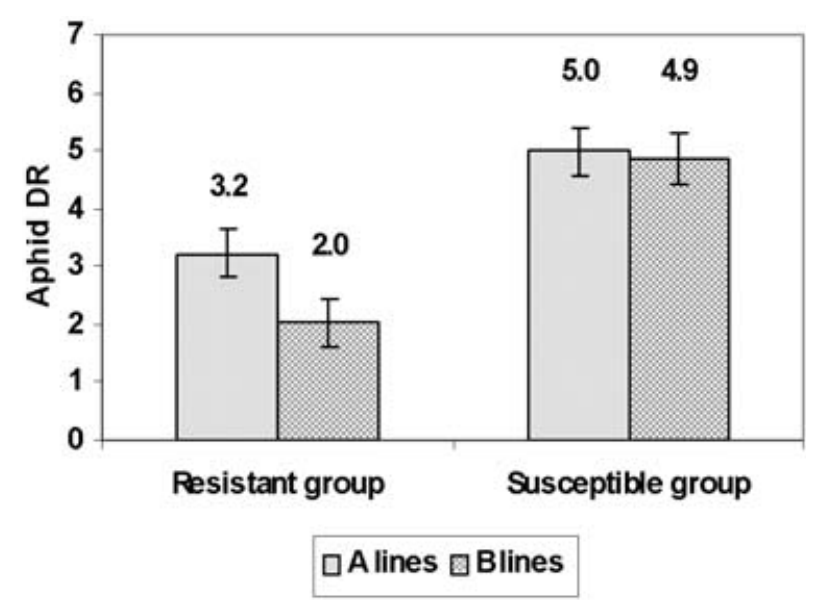

Figure 4 Effect of CMS on sugarcane aphid, Melanaphis sacchari damage in resistant and susceptible groups of CMS (A) and maintainer (B) lines of sorghum. $D R=$ damage rating $(1-9)[205]$

differences were not apparent in the case of susceptible CMS and the maintainers [205] (Figures 3 and 4). The Alines, in general, suffered greater damage than the corresponding B-lines (except in the case of stem borer), suggesting that factors in the cytoplasm of the maintainer line influence the expression of resistance to insects. The stem borer, Chilo partellus (Swinhoe)-resistant CMS and maintainer lines had a similar level of deadheart formation, while the stem borer-susceptible maintainers suffered more damage than the CMS lines (Figure 5) [205]. Expression of resistance may also be influenced by the interaction of factors in the cytoplasm of maintainer lines with the nuclear genes. Hybrids based on shoot bug (Figure 6), sugarcane aphid (Figure 7), sorghum midge (Figure 8), and shoot fly (Figure 9)-resistant CMS and restorer lines suffer less damage than the hybrids based

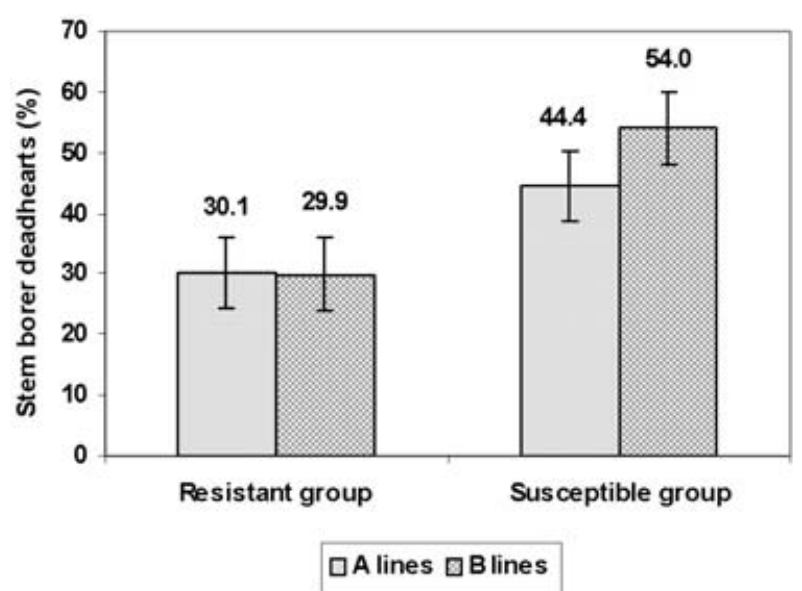

Figure 5 Effect of CMS on expression of resistance to spotted stem borer, Chilo partellus in resistant and susceptible groups of CMS (A) and maintainer (B) lines of sorghum [205]

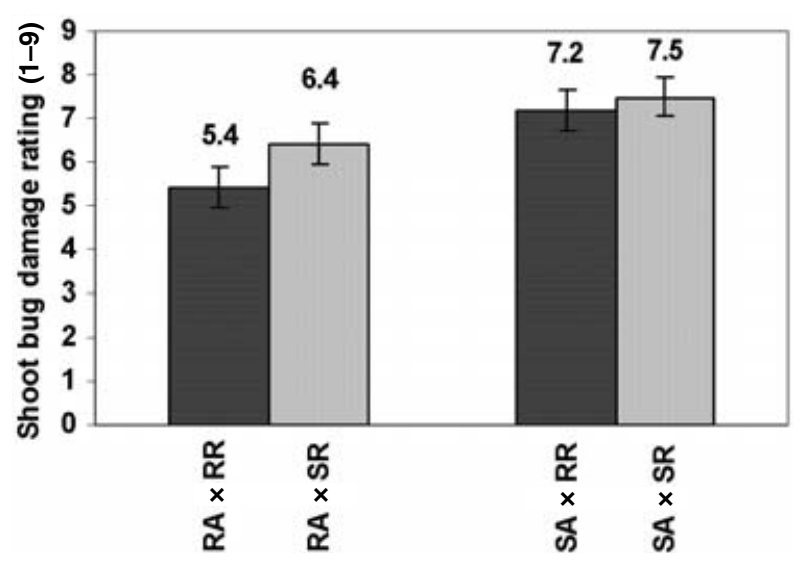

Figure 6 Influence of CMS on expression of resistance to shoot bug, $P$. maidis in sorghum hybrids based on insectresistant or -susceptible CMS and restorer lines. $R A=$ resistant $C M S(A)$ lines; $S A=$ susceptible $C M S(A)$ lines; $R R=$ resistant restorer lines; $S R=$ susceptible restorer lines [197, 201, 205]

on susceptible CMS and resistant or susceptible restorer lines, suggesting that the expression of resistance to these insects is influenced by the genetic background of the CMS lines [197, 201, 206, 207]. However, the hybrids based on stem borer-resistant or susceptible CMS lines with resistant restorers showed significantly lower deadheart formation as compared with the hybrids based on stem borer-resistant or -susceptible CMS lines and -susceptible restorers (Figure 10), suggesting that restorer lines exercised a greater influence on expression of resistance to stem borer in sorghum [205]. Similar results have also been reported for expression of resistance to stem borers, C. partellus and Busseola fusca (Fuller) in maize [208]. The $A_{4} M$ cytoplasm has been found to be comparatively resistant to $A$. soccata damage than the $A_{1}, A_{2}, A_{3}$ or $A_{4} G, A_{4} V z M$ cytoplasms $[28,109]$. 


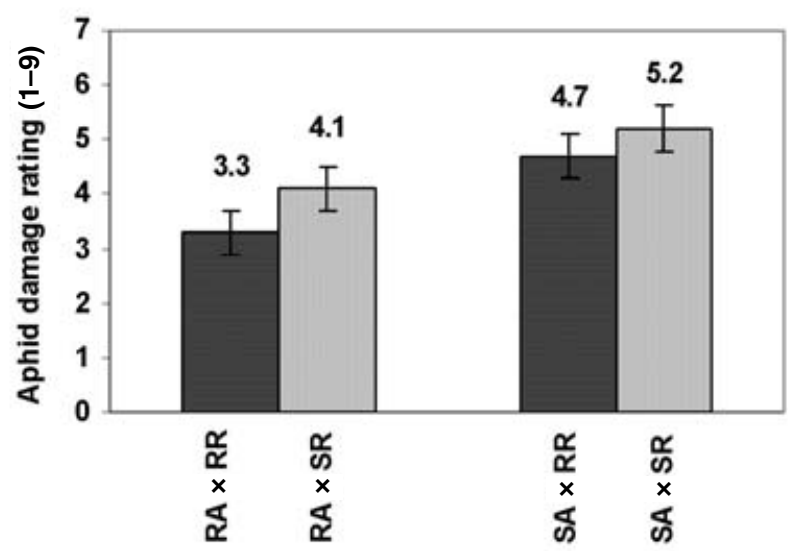

Figure 7 Influence of CMS on expression of resistance to sugarcane aphid, $M$. sacchari in sorghum hybrids based on insect-resistant or -susceptible CMS and restorer lines. $R A=$ resistant $C M S(A)$ lines; $S A=$ Susceptible CMS (A) lines; $R R=$ resistant restorer lines; $S R=$ susceptible restorer lines [197, 201, 205]

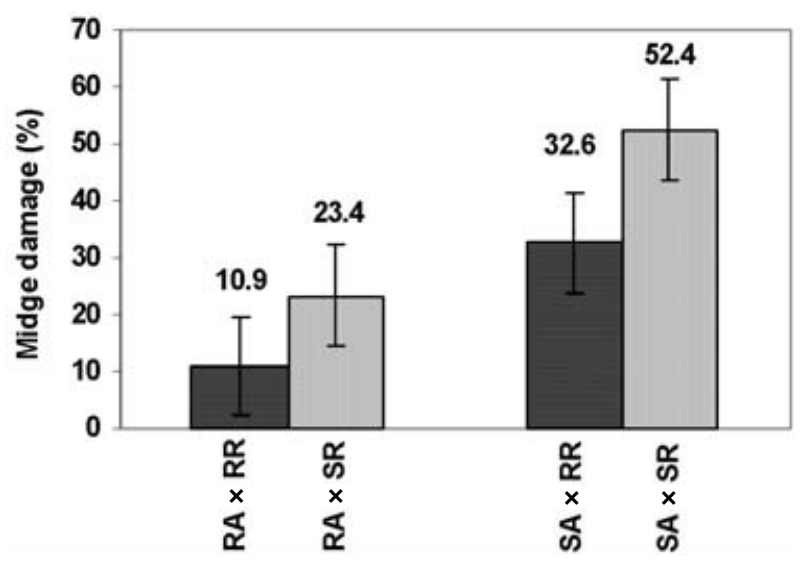

Figure 8 Influence of CMS on expression of resistance to midge, $S$. sorghicola in sorghum hybrids based on insect-resistant or -susceptible CMS and restorer lines. $R A=$ resistant CMS (A) lines; $S A=$ susceptible CMS (A) lines; $\mathrm{RR}=$ resistant restorer lines; $\mathrm{SR}=$ susceptible restorer lines [197, 201, 205]

The $\mathrm{A}_{4} \mathrm{M}$ (Maldandi) cytoplasm in combination with shoot fly-resistant restorers can be used to produce sorghum hybrids with high levels of resistance to this pest [28].

\section{Conclusions}

Considerable information has been generated on effects of CMS on morphological and physiological characteristics in different crop plants, and on the influence of CMS on expression of resistance to insect pests and plant pathogens. There is a continuing need to evaluate different cytoplasms for their effects on cultivar susceptibility to pest insects and diseases. The analyses of literature

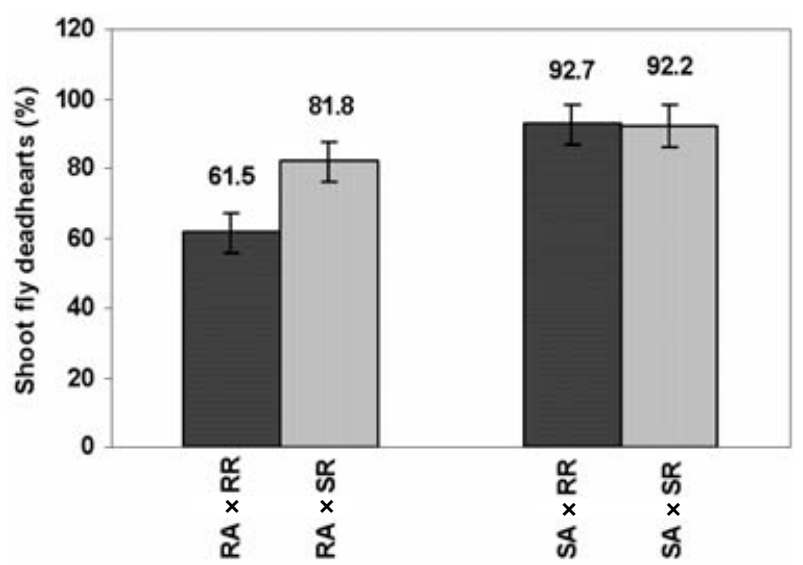

Figure 9 Influence of CMS on expression of resistance to shoot fly, $A$. soccata in sorghum hybrids based on insect-resistant or -susceptible CMS and restorer lines. $R A=$ resistant CMS (A) lines; SA=susceptible CMS (A) lines; $R R=$ resistant restorer lines; $S R=$ susceptible restorer lines [197, 201, 205, 207]

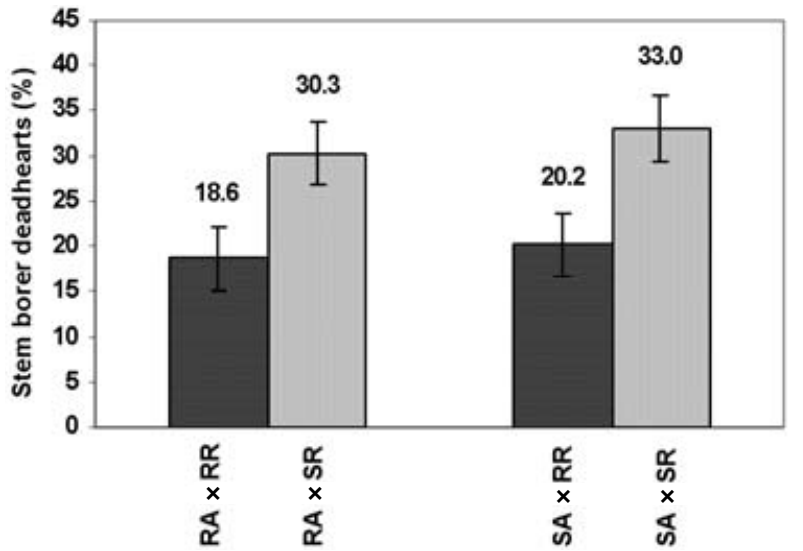

Figure 10 Influence of CMS on expression of resistance to spotted stem borer, C. partellus in sorghum hybrids based on insect-resistant or -susceptible CMS and restorer lines. $R A=$ resistant $C M S(A)$ lines; $S A=$ susceptible $C M S$ (A) lines; $R R=$ resistant restorer lines; $S R=$ susceptible restorer lines [205]

available on different CMS systems in cereals suggested that the genetic background of CMS, cytoplasmic factors, the interactions of the factors in the cytoplasm of maintainer lines with the nuclear genes, and the restoration abilities of the restorers influence the expression of resistance to insect pests and diseases. Therefore, it will be desirable to use more than one source of CMS in different genetic backgrounds as a safeguard against outbreaks of major pest insects and diseases in different crops. There is an urgent need to convert various sources of resistance to insect pests and diseases into CMS, maintainer, and restorer lines, so as to be able to develop hybrids with increased levels and diverse mechanisms of resistance to the target pests. 


\section{References}

1. Kaul MLH. Male sterility in higher plants. In: Frankel R, Grossman M, Maliga P, editors. Monographs Theoretical and Applied Genetics, Volume 10. Springer, Berlin, Heidelberg, New York; 1988. 1005. p.

2. Fukasawa $\mathrm{H}$. Studies on restoration and substitution of nucleus (genome) in Aegilotricum I. Appearance of male sterile durum in substitution crosses. Cytologia 1957;18: $167-75$.

3. Erickson JR. Biochemical investigations of cytoplasmic male sterility in spring wheat (Triticum aestivum L.). Agronomy Abstracts 1967; p. 8-9.

4. Savchenko NI, Belons VE, Scraya LV. Biochemical peculiarities of winter lines with cytoplasmic male sterility. Tistol Genetics Kiev USSR 1968;2:226-31.

5. Brooks MH. Nucleic acid studies of fertile cytoplasmic male sterile and fertility restorer in Sorghum vulgare. Sorghum Newsletter 1965;8:54-5.

6. Alam S, Sandal PC. Electrophoretic analysis of anther proteins from male fertile and male sterile sudangrass Sorghum vulgare var. sudanensis (Piper). Crop Science 1969;9:157-9.

7. Mian HR, Kuspira J, Walker GWR, Muntagewerff N. Histological and cytological studies on five genetic male sterile lines of barley (Hordeum vulgare). Canadian Journal of Genetics and Cytology 1974;16:355-79.

8. Chen JM, Qin TC. Anther nucleic acid content at various developmental stages of male sterile wheat (Triticum aestivum L.). Jiangsu Journal of Agricultural Science 1989;5:14-19.

9. Anonymous. The relationship between male sterility of rice and activities of some enzymes and rate of respiration in pollen. Acta Botanica Sinica 1977;20:150-3.

10. Watson CV, Nath J, Nanda D. Possible mitochondrial involvement in mechanism of cytoplasmic male sterility in maize (Zea mays). Biochemical Genetics 1977;15:1113-24.

11. Senthil N, Palanisamy $S$, Manickam A. Peroxidase activity in sorghum anthers. Crop Research (Hisar) 1994;8:194-5.

12. Senthil N, Manickam A. Peroxidase activity in sorghum anthers. Annals of Agricultural Research 1995;16:104-5.

13. Overman MA, Warmke HE. Cytoplasmic male sterility in Sorghum II. Tapetal behavior in fertile and sterile anthers. Journal of Heredity 1972;63:227-34.

14. Shi CH, Xue JM, Yu YG, Yang XE, Zhu J. Analysis of genetic effects on nutrient quality traits in indica rice. Theoretical and Applied Genetics 1996;92:1099-102.

15. Shi CH, Zhu J, Yang XE, Xue JM, Yu YG. Analysis of genetic effects and correlations for nutrient quality traits of indica rice in different environments. Chinese Rice Research Newsletter 1997;5:2-4.

16. Shu QY, Wu DX, Xia YW, Gao MW, McClung A. Studies on the apparent amylose content and starch viscosity of indica hybrid rice. Journal of Zhejiang Agricultural University 1998;24:621-6.

17. Savchenko NI, Borisyok VA, Enko II. Pigments in vegetative organs of wheat plants with cytoplasmic male sterility. Tistol Genetics USSR 1974;8:487-91.
18. Xia T, Liu JL. Study of the relation between auxin, zeatin and cytoplasmic male sterility in maize. Acta Agronomica Sinica 1994;20:26-32.

19. Murty BR, Thakur RP, Mehta SL, Srivastava KN. Physiological analysis of cytoplasmic differentiation in pearl millet. Proceedings of the Indian National Science Academy 1997;63B:333-48.

20. Chhabra AK, Rai KN, Khairwal IS, Hash CT, Murthy AK. Influence of sterility-inducing cytoplasms on meiosis and pollen sterility in pearl millet (Pennisetum glaucum (L.) R. Br.). National Journal of Plant Improvement 2001;3:85-91.

21. Stephens JC, Holland RF. Cytoplasmic male sterility for hybrid sorghum seed production. Agronomy Journal 1954;46:20-3.

22. Quinby JR. Origin of hybrid sorghum. In: Sorghum Improvement and the Genetics of Growth. Texas A\&M University Press, TX, USA; 1974. p. 9-17.

23. Schertz KF, Pring DR. Cytoplasmic male sterility systems in sorghum. In: House LR, Mughogho LK, Peacock JM, editors. Sorghum in the Eighties. International Crops Research Institute for the Semi-Arid Tropics, Patancheru 502324 , Andhra Pradesh, India; 1982. p. 373-83.

24. Schertz KF, Sotomayor RA, Torres C. Cytoplasmic male sterility-opportunities in breeding and genetics. In: Hang F, editor. Proceedings of the National Biam Sorghum Production Association, 16th Biennial Grain Sorghum Research Utility Conference. Lubbock, TX, USA; 1989. p. $175-86$.

25. Nagur T. Studies on fertility restoration and combining ability in relation to genetic diversity and cytoplasmic constitution in sorghum [PhD dissertation]. Tamil Nadu Agricultural University, Coimbatore, Tamil Nadu, India; 1971.

26. Xu GW, Cui YX, Schertz KF, Hart GE. Isolation of mitochondrial DNA sequences that distinguish male-sterilityinducing cytoplasms in Sorghum bicolor (L.) Moench. Theoretical and Applied Genetics 1995;90:1180-7.

27. Schertz KF, Sivaramakrishnan S, Hanna WW, Mullet J, Sun Y, Murty UR, et al. Alternate cytoplasms and apomixes of sorghum and pearl millet. Proceedings of the International Conference on Genetic Improvement of Sorghum Pearl Millet, 22-27 September 1996, Holiday Inn Plaza, Lubbock, TX, USA; 1997. p. 213-23.

28. Dhillon MK, Sharma HC, Reddy BVS, Singh R, Naresh JS, Kai Z. Relative susceptibility of different male-sterile cytoplasms in sorghum to shoot fly, Atherigona soccata. Euphytica 2005;144:275-83.

29. Pring DR, Tang HV, Shaw L, Mullen JA, Kempken F, Salazar $\mathrm{R}$, et al. DNA rearrangements and cytoplasmic male sterility in Sorghum. In: Brennicke A, editor. Plant Mitochondria with Emphasis on RNA Editing and Cytoplasmic Male Sterility. VCH Verlagsgesellschaft $\mathrm{mbH}$, Weinheim, Germany; 1993. p. 367-74.

30. Tang HV, Pring DR, Muza FR, Yan B. Sorghum mitochondrial orf25 and a related chimeric configuration of a male-sterile sorghum. Current Genetics 1996;29:285-94.

31. Sivaramakrishnan S, Seetha K, Reddy BVS. Characterization of the $\mathrm{A}_{4}$ cytoplasmic male-sterile lines of sorghum using RFLP of mt DNA. Euphytica 1997;93:301-5.

32. Howad W, Kempken F. Cell type-specific loss of atp6 RNA editing in cytoplasmic male sterile Sorghum bicolor. 
Proceedings of the National Academy of Sciences, USA $1997 ; 94: 11090-5$

33. Pring DR, Tang HV. Mitochondrial atp6 transcript editing during microgametogenesis in male-sterile sorghum. Current Genetics 2001;39:371-6.

34. Tang HV, Pring DR, Shaw LC, Salazar FA, Muza FR, Yan B, et al. Transcript processing internal to a mitochondrial open reading frame is correlated with fertility restoration in male-sterile sorghum. Plant Journal 1996;10:123-33.

35. Tang HV, Chang RY, Pring DR. Co-segregation of single genes associated with fertility restoration and transcript processing of sorghum mitochondrial orf 107 and urf 209. Genetics 1998;150:383-91.

36. Tang HV, Chen W, Pring DR. Mitochondrial orf 107 transcription, editing, and nucleolytic cleavage conferred by the gene $R f 3$ are expressed in sorghum pollen. Sexual Plant Reproduction 1999;12:53-9.

37. Chase DC, Pring DR. Properties of the linear N1 and N2 plasmid-like DNAs from mitochondria of cytoplasmic male-sterile Sorghum bicolor. Plant Molecular Biology 1986; 6:53-64.

38. Liang $\mathrm{GH}$. Analysis of cytoplasmic genomes using restriction endonucleases. Sorghum Newsletter 1991;32:7-8.

39. Bailey Serres J, Dixon LK, Liddell AD, Leaver CJ. Nuclearmitochondrial interactions in cytoplasmic male-sterile sorghum. Theoretical and Applied Genetics 1986;73:252-60.

40. Pring DR, Chen W, Tang HV, Howad W, Kempken F. Interaction of mitochondrial RNA editing and nucleolytic processing in the restoration of male fertility in sorghum. Current Genetics 1998;33:429-36.

41. Mullen JA, Pring DR, Kempken F, Ferguson F, Ferguson J, Chase CD. Sorghum mitochondrial atp6: divergent amino extensions to a conserved core polypeptide. Plant Molecular Biology 1992;20:71-9.

42. Thin T, Skinner DZ, Muthukrishnan S, Liang GH. Chloroplast DNA restriction endonuclease fragment patterns of male sterility-inducing cytoplasms. Sorghum Newsletter 1993; $34: 32$.

43. Sane AP, Nath $P$, Sane PV. Cytoplasmic male sterility in sorghum: organization and expression of mitochondrial genes in Indian CMS cytoplasms. Journal of Genetics 1996;75:151-9.

44. Nath P, Arora J, Sane PV, Moss JP. Role of mitochondria in cytoplasmic male sterility in sorghum. In: Biotechnology and Crop Improvement in Asia. International Crops Research Institute for the Semi-Arid Tropics, Patancheru 502324 , Andhra Pradesh, India; 1992. p. 357-8.

45. Arora J, Nath P, Sane PV. Association of mitochondrial electron transport activity with cytoplasmic male sterility in Sorghum bicolor. Indian Journal of Experimental Biology 1993;31:182-7.

46. Sane AP, Nath P, Sane PV. Mitochondrial ATP synthase genes may be implicated in cytoplasmic male sterility in Sorghum bicolor. Journal of Bioscience 1994;19:43-55.

47. Chen ZJ, Liang GH, Muthukrishnan S, Kofoid KD. Chloroplast DNA polymorphism in fertile and male-sterile cytoplasms of sorghum [Sorghum bicolor (L.) Moench]. Theoretical and Applied Genetics 1990;80:727-31.

48. Shan LQ, Ai PJ, Yiu LT, Yao ZF. New grain sorghum cytoplasmic male-sterile line $A_{2} V_{4} A$ and $F_{1}$ hybrid Jinza
No. 12 for Northwest China. International Sorghum Millets Newsletter 2000;41:31-2.

49. Sampath S, Mohanty HK. Cytology of semisterile hybrid rice. Current Science 1954;23:182-3.

50. Athwal DS, Virmani SS. Cytoplasmic male sterility and hybrid breeding in rice. In: Rice Breeding. International Rice Research Institute, Manila, Philippines; 1972. p. 615-20.

51. Li S, Yang D, Zhu Y. Characterization and use of male sterility in hybrid rice breeding. Journal of Integrative Plant Biology 2007;49:791-804.

52. Virmani SS, Edwards Ian B. Current status and future prospects for breeding hybrid rice and wheat. Advances in Agronomy 1970;36:145-214.

53. Li Z, Zhu Y. Rice male sterile cytoplasm and fertility restoration. Proceedings of the International Rice Symposium on Hybrid Rice, 6-10 October 1986; Changsha, China. International Rice Research Institute, Manila, Philippines; 1988. p. $17-45$.

54. Virmani SS, Shinjyo C. Current status of analysis and symbols for male sterile cytoplasms and fertility restoring genes. Rice Genetics Newsletter 1988;5:9-15.

55. Virmani SS, Wan BH. Development of CMS lines in hybrid rice breeding. In: Rice Breeding. International Rice Research Institute, Manila, Philippines; 1988. p. 103-14.

56. Virmani SS. Heterosis and Hybrid Rice Breeding. Springer, Berlin Heidelberg, New York; 1994, 280 p.

57. Li DD, Wang B. Rice atpA gene cloning and its relationship with cytoplasmic male sterility. Hereditas Beijing 1990; 12:1-4.

58. Kadowaki KI, Suzuki T, Kazama S. A chimeric gene containing the 5' portion of atp6 is associated with cytoplasmic male-sterility of rice. Molecular and General Genetics 1990; 224:10-16.

59. Wang B, Li YN, Zhang XW, Hu L, Wang JZ. Double-stranded DNA and male sterility in rice. Theoretical and Applied Genetics 1990;79:556-60.

60. Xu RL, Xie D, Shuai SY, Guo W. Cloning and sequence analysis of a specific mitochondrial DNA and fragment related to wild abortive type cytoplasmic male sterility in rice. Acta Botanica Sinica 1995;37:501-6.

61. Pei DS, Cai PZ, Li MY, Xiang YW, Yan WZ, Zhang ZX, et al. Screening of RAPD markers for sterility gene of nucleocytoplasmic interaction in mitochondrial DNA of rice. Acta Agronomica Sinica 2003;29:899-902.

62. Eckardt NA. Cytoplasmic male sterility and fertility restoration. The Plant Cell 2006;18:515-7.

63. Ahmadikhah A, Karlov GI, Nematzadeh Gh, Ghasemi Bezdi $\mathrm{K}$. Inheritance of the fertility restoration and genotyping of rice lines at the restoring fertility $(R f)$ loci using molecular markers. International Journal of Plant Production 2007;1:13-21.

64. Zhang G, Bharaj TS, Lu Y, Virmani SS, Huang N. Mapping of the Rf3 nuclear fertility-restoring gene for WA cytoplasmic male sterility in rice using RAPD and RFLP markers. Theoretical and Applied Genetics 1997;94:27-33.

65. Ahmadikhah A, Karlov GI. Molecular mapping of the fertilityrestoration gene $R f 4$ for WA-cytoplasmic male sterility in rice. Plant Breeding 2006;1215:363-7.

66. Akagi $\mathrm{H}$, Nakamura A, Yokozeki $\mathrm{Y}$, Inagaki A, Takahashi $\mathrm{H}$, Mori $\mathrm{K}$, et al. Positional cloning of the rice Rf-1 gene, a 
restorer of BT-type cytoplasmic male sterility that encodes a mitochondria-targeting PPR protein. Theoretical and Applied Genetics 2004;108:1449-57.

67. Kazama T, Toriyama K. A pentatricopeptide repeatcontaining gene that promotes the processing of aberrant apt6 RNA of cytoplasmic male-sterile rice. FEBS Letter 2003;544:99-102.

68. Komori T, Yamamoto T, Takemori N, Kashihara M, Matsushima $\mathrm{H}$, Nitta N. Fine genetic mapping of the nuclear gene, Rf1, that restores the BT-type cytoplasmic male sterility in rice (Oryza sativa L.) by PCR-based markers. Euphytica 2003;129:241-7.

69. Komori T, Ohta S, Murai N, Takakura Y, Kuraya Y, Suzuki S et al. Map-based cloning of a fertility restorer gene, Rf-1, in rice (Oryza sativa L.). Plant Journal 2004;37:315-25.

70. Kihara $\mathrm{H}$. Substitution of nucleus and its effects on genome manifestations. Cytologia 1951;16:177-93.

71. Wilson JA, Ross WM. Male sterility interaction of the Triticum timopheevi cytoplasm. Wheat Information Service Kyoto University 1962;14:29-30.

72. Murai K, Ogihara Y, Tsunewaki K. An EMS induced mutant restoring fertility against photoperiod sensitive cytoplasmic male sterility. Plant Breeding 1995;114:205-9.

73. Toriyama K, Tsunewaki K, Nonaka S, Shimada T. A breeding scheme proposed for hybrid wheat utilizing male sterility induced by the interaction between an SV type cytoplasm and a IBL-IRS chromosome. Japanese Journal of Breeding 1993;43:516-24.

74. Ma ZQ, Sorrells ME. Genetic analysis of fertility restoration in wheat using restriction fragment length polymorphisms. Crop Science 1995;35:1137-43.

75. Rhodes MM. Cytoplasmic inheritance of male sterility in Zea mays. Science 1931;73:340-1.

76. Duvick DN. Cytoplasmic pollen sterility in corn. Advance Genetics 1965;13:1-56.

77. Beckett JB. Classification of male sterile cytoplasms in maize (Zea mays L.). Crop Science 1971;11:724-7.

78. Tatum LA. The southern corn leaf blight epidemic. Science 1971;171:1113-6.

79. Glab N, Petit PX, Slonimski PP. Mitochondrial dysfunction in yeast expressing the cytoplasmic male sterility $T$-urf13 gene from maize: analysis at the population and individual cell level. Molecular and General Genetics 1993;236: 299-308.

80. Fauron CMR, Havlik M. Recombination event in cms-T regenerated plants during reversion to fertility. Maize Genetics and Cooperative Newsletter 1990;64:102-3.

81. Gallagher LJ, Betz SK, Chase CD. Mitochondrial RNA editing truncates a chimeric open reading frame associated with S male-sterility in maize. Current Genetics 2002;42: 179-84.

82. Zabala G, Gabay Laughnan S, Laughnan JR. The nuclear gene Rf3 affects the expression of the mitochondrial chimeric sequence $\mathrm{R}$ implicated in S-type male sterility in maize. Genetics 1997;147:847-60.

83. Glab N, Wise RP, Pring DR, Jacq C, Slonimski P. Expression in Saccharomyces cerevisiae of a gene associated with cytoplasmic male sterility from maize: respiratory disfunction and uncoupling of yeast mitochondria. Molecular and General Genetics 1990;223:24-32.

84. Budar F. Mitochondrial chimeric genes and male sterility. Comptes Rendus des Seances de la Societe de Biologie et de ses Filiales 1995;189:1105-17.

85. Levings CS III, Pring DR. Restriction endonuclease analysis of mitochondrial DNA from normal and Texas cytoplasmic male-sterile maize. Science 1976;193:158-60.

86. Pring DR, Levings CS III. Heterozygosity of maize cytoplasmic genomes among male-terile cytoplasms. Genetics 1978;89:121-36.

87. Li J, Liu YN. Chloroplast DNA and cytoplasmic male-sterility. Theoretical and Applied Genetics 1983;64:231-8.

88. Tang JH, Liu ZH, Chen WC, Hu YM, Ji HQ, Ji LY, et al. Mapping major restore genes for $\mathrm{C}$-type cytoplasmic male sterility in maize with SSR marker. Agricultural Science China 2002;1:269-73.

89. Tang JH, Liu ZH, Chen WC, Hu YM, Ji HQ, Ji LY. The SSR markers of the main restorer genes for CMS-C cytoplasmic male sterility in maize. Sciencia Agricultura Sinica 2001; 34:592-6.

90. Tang JH, Hu YM, Ji HQ, Chen WC, Ji LY, Zheng YK. The SSR marker of the restoring gene Rf4 for CMS-C cytoplasmic male sterility in maize. Journal of Henan Agricultural University 2001;35:1-3.

91. Tang JH, Ji HQ, Huang ZW, Ji LY, Wang CH. Mapping of the main restoring gene (Rf4) of C-cytoplasmic male sterility in maize with RFLP. Journal of Henan Agricultural University 2001;35:99-102.

92. Burton GW, Athwal DS. Two additional sources of cytoplasmic male sterility in pearl millet and their relationship to Tift 23A. Crop Science 1967;7:209-11.

93. Hanna WW. Characteristics and stability of a new cytoplasmic-nuclear male sterile source in pearl millet. Crop Science 1989;29:1457-9.

94. Delorme V, Keen CL, Rai KN, Leaver CJ. Cytoplasmicnuclear male sterility in pearl millet: comparative RFLP and transcript analyses of isonuclear male-sterile lines. Theoretical and Applied Genetics 1997;95:961-8.

95. Sujata V, Sivaramakrishnan S, Rai KN, Seetha K. A new source of cytoplasmic male sterility in pearl millet: RFLP analysis of mitochondrial DNA. Genome 1994;37:482-6.

96. Schooler AB. A form of male sterility in barley hybrids. Journal of Heredity 1967;58:206-11.

97. Foster AE, Schooler AB. Cytoplasmic male sterility in barley. Barley Genetics Newsletter 1971;2:316-8.

98. Shao Q, Li A, Cao L. OV type gene-cytoplasmic male sterile lines of barley. Genetic Manipulation in Plants 1991;7:108.

99. Ahokas H. Cytoplasmic male sterility in barley. XI. The $\mathrm{msm}_{2}$ cytoplasm. Genetics 1982;102:285-95.

100. Ahokas H. Cytoplasmic male sterility in barley. XIV. Evidence for the involvement of cytokinins in fertility restoration. Proceedings of the National Academy of Sciences, USA 1982;79:7605-8.

101. Hockett EA, Aastveit K, Gilbertson KM. Selfing behavior of cytoplasmic male sterile barley in Norway and the United States. Hereditas 1989;111:167-9. 
102. Franckowiak JD. Identification of two additional loci that control genetic male sterility in barley. Barley Genetics Newsletter 1992;22:10-11.

103. Matsui K, Mano Y, Taketa S, Kawada N, Komatsuda T. Molecular mapping of a fertility restoration locus (Rfm1) for cytoplasmic male sterility in barley (Hordeum vulgare L.). Theoretical and Applied Genetics 2001;102:477-82.

104. Lenz MC, Atkins RE. Comparisons of agronomic and morphologic characters in sorghums having different cytoplasms. Crop Science 1981;21:946-50.

105. Ross WM, Kofoid KD. Effect of non-milo cytoplasms on the agronomic performance of sorghum. Crop Science 1979, 19:267-70.

106. Williams Alanis H, Rodriguez Herrera R. Cytoplasmic-genic male sterility effect in flowering of sorghum isogenic lines. Sorghum Newsletter 1992;33:17.

107. Williams Alanis H, Rodriguez Herrera R, Aguirre Rodriguez J, Torres Montalvo $\mathrm{H}$. Comparative performance of isogenic sorghums in $A_{1}$ and $A_{2}$ cytoplasms. II. Yield and Agronomic characteristics. Sorghum Newsletter 1993;34:51.

108. Williams Alanis $\mathrm{H}$, Rodriguez Herrera R. Comparative performance of sorghums in $A_{1}$ and $A_{2}$ cytoplasms. II. Yield and agronomic characteristics. Cereals Research Communication 1994:22:301-7.

109. Dhillon MK. Effects of cytoplasmic male-sterility on expression of resistance to sorghum shoot fly, Atherigona soccata (Rondani) [PhD dissertation]. Chaudhary Charan Singh Haryana Agricultural University, Hisar, Haryana, India; 2004. $382 p$

110. Dhillon MK, Sharma HC, Reddy BVS. Agronomic desirability of different sources of cytoplasmic male-sterility systems and their reaction to sorghum shoot fly, Atherigona soccata. International Sorghum and Millets Newsletter 2005:46:52-5.

111. Williams Alanis $\mathrm{H}$, Rodriguez Herrera R. Combining ability on isogenic sorghums in $A_{1}$ and $A_{2}$ cytoplasms. International Sorghum and Millets Newsletter 1994;35:75.

112. Secrist RE, Atkins RE. Pollen fertility and agronomic performance of sorghum hybrids with different male-sterilityinducing cytoplasms. Journal of lowa Academy of Science 1989;96:99-103

113. Gangakishan A, Borikar ST. Comparative performance of Maldandi V/S Milo cytoplasm in sorghum. Journal of Maharashtra Agricultural University 1989;14:192-5.

114. Wang B, Li YN, Zhang XW, Hu L, Wang JZ. Evaluation of $A_{2}$ male-sterile lines in sorghum. II. Combining ability analysis for main agronomic characters. Theoretical and Applied Genetics 1990;79:556-60.

115. Pecina Quintero V, Navarro Guerrero E, Williams Alanis $\mathrm{H}$, Rodriguez Herrera R. Characteristics of a new source of male sterility in four isocytoplasmic sorghum lines. Revista Fitotecnia Mexicana 1994;17:48-54.

116. Kishan AG, Choulwar SS, Shinde SS, Borikar ST. Character association in relation to cytoplasmic diversity in sorghum. Journal of Maharashtra Agricultural University 1991;16: $123-4$.

117. Senthil N, Palanisamy S. Fertility restoration studies on diverse cytosteriles of sorghum. Journal of Maharashtra Agricultural University 1995;20:159-60.
118. Chen $Y$, Sun $G H$, Shi $Y X$, Miller FR. Fertility reaction of partial conversion lines with different cytoplasms in sorghum. Acta Agronomica Sinica 1995;21:281-8.

119. Nurbekov SI. Heterosis in wheat hybrids in relation to the genotype of the parent forms. In: Problemy teoreticheskoi i Prikladnoi Genetiki v Kazakhstane: Materialy Respublikanskoi Konferentsii, 18-22 Noyabrya 1990, Alma Ata; 1990. p. 26-7.

120. Pederson JF, Toy JJ. Forage yield, quality, and fertility of sorghum $\times$ sudangrass hybrids in $A_{1}$ and $A_{3}$ cytoplasm. Crop Science 1997;37:1973-5.

121. Zhonggi L, Youchun L. Heterosis of grain weight in wheat hybrids with Triticum timopheevi cytoplasm. Euphytica 1994;75:189-93.

122. Nonaka S, Tanida Y, Toriyama K, Tsunewaki K. Effects of the IBL-IRS translocation chromosome on agronomic traits of wheat cultivars. Taichung District Agricultural Improvement Station 1994;35 Special Publication:45-151.

123. Nonaka S, Toriyama K, Tsunewaki K, Shimada T, Cotoh K, Komatsu T, et al. Effect of an SV cytoplasm and a IBL-IRS chromosome on agronomic traits of wheat cultivars, Triticum aestivum. Breeding Science 1994;44:295-9 and 340-1.

124. Wang SJ, Liu SY, Kang MH, Hang XQ. A study of cytoplasmic effect in the AL-type cytoplasmic male sterile wheat (Triticum aestivum). Acta Agricultura Boreali Sinica 1996;11:49-53.

125. Goral $\mathrm{H}$, Spiss L. Utilization of cytoplasmic male sterility in obtaining triticale hybrids. Zoszyty Naukowo Akademii Rolniezej w Szezecinic, Rolnictwo 1997;65(1):109-14.

126. Goral H, Spiss L. Effect of sterile cytoplasm of T. timopheevi on agronomic traits of winter triticale hybrids. Biuletyn Instytutu Hodowli i Aklimatyzacji Roslin 1998;205-206: $157-61$.

127. Murai K. Effects of Aegilops crassa cytoplasm on the agronomic characters in photoperiod-sensitive CMS wheat lines and $F_{1}$ hybrids. Breeding Science 1997;47:321-6.

128. Li YC, Liu ZQ. Heterosis and effect of the Rht3 gene on plant height and its components in hybrid bread wheat with T. timopheevii cytoplasm. Breeding Science 1995;45:419-23.

129. Busch RH, Mann SS. Effects of alien cytoplasms on agronomic and bread making traits of two spring wheat cultivars. Crop Science 1978;18:864-6.

130. Keane EM, Jones PW. Effects of alien cytoplasm substitution on the response of wheat cultivars to Septoria nodorum. Annals of Applied Biology 1990;117:299-12.

131. Busch RH, Rauch TL. Alien cytoplasmic effects on agronomic performance of two high yielding semi dwarf spring wheat cultivars. Crop Science 1994;34:389-91.

132. Zhang LL, Zhang YJ. A comparative study on wheat CMS lines with Aegilops juvenalis and Ae. Kotschyi cytoplasm. Journal of Hubei Agricultural College 2001;21:193-5.

133. Sun DF. Selection and genetic analysis of nucleocytoplasmic male sterile line 88B CMS in barley. Sciencia Agricultura Sinica 1995;28:31-6.

134. Gramatikova M, Gorastev C. Characteristics of cytoplasmic male sterile winter barley lines. Barley Genetics Newsletter 1992:21:27-30.

135. Mani SC, Singh H, Singh JP, Singh S, Singh D. Evaluation of some CMS lines and their maintainers under tarai conditions 
of western U.P. Current Research, University of Agricultural Sciences, Bangalore 1989;10:137-9.

136. Muker HS, Sharma HL. Effect of WA male sterile cytoplasm in rice. Tropical Science 1993;33:209-12.

137. Cai SX. Studies on effects of male sterile cytoplasm in rice (Oryza sativa L. indica and Oryza sativa L. f. spontanea). Journal of South China Agricultural University 1994;15: 115-21.

138. Pradhan SB, Ratho SN. Studies on internode and certain other characters in relation to cytoplasmic-genetic male sterile lines in rice. Botanica Bulletin Academia Sinica 1990;31:217-21.

139. Wang CL, Tang YG. Studies on the genetic effects of sterile cytoplasm in hybrid rice (Oryza sativa L. subsp. sinica). Acta Agronomica Sinica 1990;16:335-41.

140. Wang CL, Tang SH, Tang YG. Genetic effects of sterile cytoplasm of isonuclear alloplasmic CMS lines in hybrid rice (Oryza sativa L. subsp. japonica). Chinese Journal of Rice Science 1998;12:65-71.

141. Tang SZ, Gu MH, Zhang ZL, Wang CL, Chen JM, Chen ZX. Analysis of genetic effects of different male sterile cytoplasms in rice on $\mathrm{R}_{1}$ major characters. Jiangsu Journal of Agricultural Science 1997;13:65-9.

142. Wang CL, Tang SZ, Tang YG. Effects of male sterile cytoplasm on yield and agronomic characters in japonica hybrid rice, Oryza sativa L. Breeding Science 1998;48: 263-71.

143. Cai SX. Effects of male sterile cytoplasms on $F_{1}$ hybrids in rice. Journal of South China Agricultural University $1997 ; 18: 81-5$.

144. Ganesan KN, Rangaswamy M. Effect of cytoplasm on rice hybrids. Crop Research (Hisar) 1997;14:55-9.

145. Lin $W X$, Liang $Y Y, W u Z Q$. Influence of environmental conditions on genetic performance, cytoplasmic effects and nucleocytoplasmic interaction in hybrid rice. V. Effects of sterile cytoplasms on photosynthetic physiology and the activities of defense enzymes in hybrid rice under different application rate of nitrogen. Chinese Journal of Applied Ecology 1996;7:364-70.

146. Lin WX, Kim KU, Shin DH, Lee IJ, He SL, Moon HP. Effect of male sterile cytoplasm on the genetic performance of agronomic traits in $\mathrm{F}_{1}$ hybrid rice. Korean Journal of Crop Science 1998;43:59-63.

147. Has V, Grecu C, Cabulea I, Has I. Effect of some male sterile cytoplasms on stability of performance in maize hybrids. Probleme de Genetica Teoretica si Aplicata 1989;21:149-69.

148. Miku VE, Partas EC. Comparative study of maize hybrids based on different types of cytoplasmic male sterility (CMS). Selektsionno Geneticheskie Issledovaniya Kukuruzy i Sorgo V Moldavii 1989; p. 45-56.

149. Miku VE, Partas EC. The effect of $C$ male sterile cytoplasm on morphological and agronomic traits of corn hybrids. Maize Genetics Cooperative Newsletter 1990;64:95-6.

150. Miku VE, Partas EK. Evaluation of hybrids based on different types of cytoplasmic male sterility (CMS). Informatsionnyi Byulleten po Kukuruze 1990;8:57-66.

151. Miku VE, Partas EK, Gutsanu KG. Hybrids bred using male sterility. Kukuruza i Sorgo 1990;5:30-3.
152. Sarca T, Ciocazanu I, Bica N, Tanislav N. Effect of the interaction of cytoplasms $\mathrm{C}$ and $\mathrm{S}$ and three sources of C-type male-sterile cytoplasm with genotype on some agronomic traits in maize (Zea mays L.). Probleme de Genetica Teoretica si Aplicata 1990;22:35-59.

153. Saratlich G, Mishovich M, Saratlic G, Misovic M. Effect of cytoplasm type on the yield of some inbred lines of maize (Zea mays L.). Informatsionnyi Byulleten po Kukuruze 1990;8:57-66.

154. Saratlich G. Effect of male sterility and type of cytoplasm on grain yield in inbred lines of maize (Zea mays L.). Zbornik Radova Poljoprivrednog Fakulteta, Univerzitet u Beogradu 1991;36:71-83.

155. Miku VE, Partas EK. Study and use of cytoplasmic male sterility (CMS) in the breeding and seed production of maize. In: Selektsiya I Semenovodstvo rannespelykh gibridov kukuruzy: Doklady Nauchno Metodicheskogo Soveshchaniya po Problemam; 1991. p. 149-63.

156. Sangoi L, Salvador R. Agronomic performance of malesterile and fertile maize genotypes at two plant populations. Ciencia Rural 1996;26:377-83.

157. Partas EK. Prospects for using new sources of cytoplasmic male sterility in the hybrid seed production of maize. Kukuruza I Sorgo 1996;3:3-5.

158. Hu YM, Luo FH, Ji LY, Ji HQ, Huang XL, Liu ZH. The feasibility of utilizing ES-type male sterile cytoplasm in maize production. Acta Agricultural University Henanensis 1999;33:1-4.

159. Virk DS, Brar JS. Assessment of cytoplasmic differences of near-isonuclear male-sterile lines in pearl millet. Theoretical and Applied Genetics 1993;87:106-12.

160. Mangat BK, Virk DS, Chahal GS. Heterosis manifestations in relation to cytosterile diversification in pearl millet. In: Verma MM, Virk DS, editors. Symposium on Heterosis Breeding in Crop Plants - Theory and Application: Short Communications, 23-24 February 1993. Punjab Agricultural University, Ludhiana, Punjab, India; 1993, p. 38-9.

161. Mangat BK, Randhawa HS, Virk DS. Grain yield potential and disease reaction of diverse pearl millet hybrids. Crop Improvement 1996;23:99-104.

162. Virk DS, Mangat BK, Chahal GS. Comparative heterotic potential of diverse male sterility sources in pearl millet. In: Verma MM, Virk DS, editors. Symposium on Heterosis Breeding in Crop Plants - Theory and Application: Short Communications, 23-24 February 1993. Punjab Agricultural University, Ludhiana, Punjab, India; 1993. p. 150-1.

163. Yadav OP. Performance of pearl millet isonuclear hybrids involving different cytoplasmic male-sterility systems. Plant Breeding 1996;115:140-2.

164. Hanna WW. Forage yield, seed weight, and influence characteristics of isogenic pearl millet hybrids with four different cytoplasms. Agronomy Journal 1982;74:879-81.

165. Andrews DJ, Rajewski JF. Male fertility restoration and attributes of the $\mathrm{A}_{4}$ cytoplasmic-nuclear male sterility system for grain production in pearl millet. International Sorghum and Millets Newsletter 1994;35:64.

166. Yadav OP. Effect of cytoplasmic source on the combining ability of agronomic traits in pearl millet. Plant Breeding 1994;113:242-5. 
167. Chhabra AK, Khairwal IS, Rai KN, Hash CT, Murthy AK. Influence of cytoplasmic nuclear male sterility systems on microsporogenesis in pearl millet (Pennisetum glaucum (L.) R. Br.). Euphytica 1997;98:1-10.

168. Kumar S, Chahal GS, Virk DS. Combining ability of diverse male sterile sources in pearl millet. Crop Improvement 1996;23:151-4.

169. Torres Montalvo H, Mendoza Onofre LE, Gonzalez Hernandez VA, Williams-Alanis $\mathrm{H}$. Reaction of tan and nontan isogenic sorghum genotypes to rust. Sorghum Newsletter 1992;33:31.

170. Torres Montalvo H, Mendoza Onofre LE, Gonzalez Hernandez VA, Williams-Alanis $\mathrm{H}$. Reaction of tan and non-tan isogenic sorghum genotypes to head blight. Sorghum Newsletter 1992;33:36.

171. Rodriguez Herrera R, Williams Alanis $\mathrm{H}$, Aguirre Rodriguez J. Incidence of head smut in isogenic sorghums for cytoplasm type. Sorghum Newsletter 1992;33:35

172. Rodriguez Herrera R, Williams Alanis $\mathrm{H}$, Aguirre Rodriguez $\mathrm{J}$. Comparative performance of isogenic sorghums in $A_{1}$ and $A_{2}$ cytoplasms. III. Head smut. Sorghum Newsletter 1993;34:22.

173. James SP, Pedersen JF. Expression of susceptibility to fusarium head blight and grain mold in $A_{1}$ and $A_{2}$ cytoplasms of Sorghum bicolor. Plant Disease 2003;87:172-6.

174. Voluevich EA, Buloichik AA. Nucleocytoplasmic interactions in the resistance of wheat to fungal pathogens. VII. Effects of alien cytoplasm in plant ontogeny following inoculation with a virulent strain of brown rust. Genetika Moskva 1994; 30:1229-33.

175. Mantle PG, Swan DJ. Effect of male sterility on ergot disease spread in wheat. Plant Pathology 1995;44:392-5.

176. Matsui K, Yoshida M, Ban T, Komatsuda T, Kawada N. Role of male sterile cytoplasm in resistance to barley yellow mosaic virus and fusarium head blight in barley. Plant Breeding 2002;121:237-40.

177. Yang RC, Lu HR, Zhang XB, Xia YH, Li WM, Liang KJ, et al. Study of the susceptibility of CMS WA cytoplasm in rice to blast and bacterial blight. Acta Agronomica Sinica 1989;15:310-8.

178. Tang LC, Zhang XB, Qiu HF. Analysis of inheritance spectrum of hybrid rice resistance to blast and optimization of its combinations. Journal of Fujian Agricultural University 1994;23:286-92.

179. Xu ZG, Song HM. Resistance to bacterial leaf blight in some CMS lines of rice. Acta Agricultura Boreali Sinica 1997; 12:46-50.

180. Xu ZGT, Kong FM, Shen XP, Cheng M. Forecasting of resistance to bacterial blight in indica hybrid rice and its parents. Journal of Southwest Agricultural University 1998;20:409-13.

181. Sharma RC, Sidhu GS, Bharaj TS, Sharma HL. Pathological constraints on hybrid rice production technology. International Rice Research Notes 1993:18:15.

182. Levings CS III. The Texas cytoplasm of maize: cytoplasmic male sterility and disease susceptibility. Science Washington 1990;250:942-7.

183. Levings CS III, Siedow JN. Molecular basis of disease susceptibility in the Texas cytoplasm of maize. Plant Molecular Biology 1992;19:135-47.
184. Fed'ko IA, Tereshchenko BA, Morshatskii AA. Specific effect of $T$ toxin and its use in studies. Selektsiya i Semenovodstvo Moskva 1989;6:18-20.

185. Gur'ev BP, Kozubenko LV, Kamyshan TP, Movchan DS, Chupikov NM. New high yielding hybrid. Kukuruza I Sorgo 1991;6:39-40.

186. Liu KM, Su H, Cui Y, Ma CH, Chen WC, Li DL. Reaction of different male-sterile cytoplasm subgroups of the $\mathrm{C}$ group maize to the infection of Bipolaris maydis race C. Sciencia Agricultura Sinica 1991;24:58-60.

187. Yadav OP, Manga VK, Gupta GK. Influence of A1 cytoplasmic substitution on the downy-mildew incidence of pearl millet. Theoretical and Applied Genetics 1993; $87: 558-60$.

188. Randhawa HS, Virk DS, Mangat BK, Chahal GS. Disease reaction of some pearl millet hybrids involving diverse cytoplasms. In: Verma MM, Virk DS, editors. Symposium on Heterosis Breeding in Crop Plants - Theory and Application: Short Communications, 23-24 February 1993 Punjab Agricultural University, Ludhiana, Punjab, India; 1993, p. 46-7.

189. Yadav OP. Effect of A1 cytoplasm on the combining ability for smut severity in pearl millet. Theoretical and Applied Genetics 1994;88:28-9.

190. Yadav OP. Influence of A1 cytoplasm in pearl millet. Plant Breeding Abstracts 1994;64:1375-9.

191. Yadav OP, Khairwal IS, Singh S. Smut severity of pearl millet hybrids with male sterile and fertile cytoplasm. Euphytica 1992;64:139-42.

192. Rai KN, Thakur RP. Ergot reaction of pearl millet hybrids affected by fertility restoration and genetic resistance of parental lines. Euphytica 1995;83:225-31.

193. Thakur RP, Rao VP, Singh SB. Ergot susceptibility in relation to cytoplasmic male sterility in pearl millet. Plant Disease 1989;73:676-8.

194. Rai KN, Thakur RP. Smut reaction of pearl millet hybrids affected by fertility restoration and genetic resistance of parental lines. Euphytica 1996;90:31-7.

195. Yadav OP. Downy mildew incidence of pearl millet hybrids with different male-sterility inducing cytoplasms. Theoretical and Applied Genetics 1996;92:278-80.

196. Sharma HC. Cytoplasmic male-sterility and source of pollen influence the expression of resistance to sorghum midge, Stenodiplosis sorghicola. Euphytica 2001 122:391-5.

197. Sharma HC, Dhillon MK, Naresh JS, Singh R, Pampapathy G, Reddy BVS. Influence of cytoplasmic male-sterility on the expression of resistance to insects in sorghum. In: Fisher T, Turner N, Angus J, McIntyre L, Robertson M, Borrell $A$, et al. editors. Fourth International Crop Science Congress, 25 September-1 October 2004. Brisbane, Queensland, Australia; 2004

198. Sharma H C, Vidyasagar P, Abraham CV, Nwanze KF. Effect of cytoplasmic male-sterility in sorghum on host plant interaction with sorghum midge, Contarinia sorghicola. Euphytica 1994;74:35-9.

199. Johnson JW. Status of breeding for midge resistance. In: 10th Biennial Grain Sorghum Research and Utilization Conference, 2-4 March 1977, Grain Sorghum Producers Association, Wichita, KS; 1977. 
200. Sharma HC, Abraham CV, Vidyasagar P, Stenhouse JW. Gene action for resistance in sorghum to midge, Contarinia sorghicola. Crop Science 1996;36:259-65.

201. Dhillon MK, Pampapathy G, Sharma HC. Effect of cytoplasmic male-sterility on expression of resistance to insects in Sorghum. In: Fifth International Sorghum Conference, 30 January-2 February 2006, Radisson Resort, Gold Coast, Australia; 2006.

202. Kumar $\mathrm{H}$, Mihm JA. Resistance in maize hybrids and inbreds to first-generation southwestern corn borer, Diatraea grandiosella (Dyar) and sugarcane borer, Diatraea saccharalis Fabricius. Crop Protection 1996;15:311-7.

203. Dhillon MK, Sharma HC, Naresh JS, Singh R, Pampapathy G. Influence of cytoplasmic male-sterility on different mechanisms of resistance in sorghum to shoot fly, Atherigona soccata. Journal of Economic Entomology 2006;99(4):1452-61.

204. Dhillon MK, Sharma HC, Singh R, Naresh JS. Influence of cytoplasmic male-sterility on expression of physico-chemical traits associated with resistance to sorghum shoot fly, Atherigona soccata. SABRAO Journal of Breeding and Genetics 2006;38:105-22.

205. Dhillon MK, Sharma HC, Pampapathy G, Reddy BVS. Cytoplasmic male-sterility affects expression of resistance to shoot bug (Peregrinus maidis), sugarcane aphid (Melanaphis sacchari) and spotted stem borer (Chilo partellus). International Sorghum and Millets Newsletter 2006;47:66-8.

206. Dhillon MK, Sharma HC, Reddy BVS, Singh R, Naresh JS. Nature of gene action for resistance to sorghum shoot fly, Atherigona soccata. Crop Science 2006;46:1377-83.

207. Sharma HC, Dhillon MK, Reddy BVS. Expression of resistance to sorghum shoot fly in $\mathrm{F}_{1}$ hybrids involving shoot fly resistant and susceptible cytoplasmic male-sterile and restorer lines of sorghum. Plant Breeding 2006;125:473-7.

208. Kumar H. Responses of Chilo partellus (Lepidoptera: Pyralidae) and Busseola fusca (Lepidoptera: Noctuidae) to hybrids of a resistant and a susceptible maize. Journal of Economic Entomology 1993;86:962-8. 